\title{
Effect of 3-Month Water-Exercise Program on Body Composition in Elderly Women
}

\author{
Efecto de Tres Meses de un Programa de Ejercicio Acuático \\ en la Composición Corporal de Adultas Mayores
}

\author{
Paulina Yesica Ochoa Martínez,"**; Javier Arturo Hall López ,,**; Edgar Ismael Alarcón Meza,**; \\ Daniel Piña Díaz ${ }^{* * * *}$ \& Martin Dantas Estélio Henrique ${ }^{* * * * * *}$
}

OCHOA, M. P. Y.; HALL, L. J. A.; ALARCón, M. E. I.; PIÑA, D. D. \& ESTÉLIO, H. M. D. Effect of 3-month of waterexercise program on body composition in elderly women. Int. J. Morphol., 32(4):1248-1253, 2014.

SUMMARY: The aim of this study was to evaluate the effect of a hydrogymnastics training program on Body fat and Fatfree mass in elderly women. The subjects were randomly divided in experimental groups that participated in the hydrogymnastics training program and control group that was not involved in the training and remained sedentary. They were assessed with anthropometric variables in accordance with ISAK protocol in order to determine Body fat (Kg), Fat-free mass (Kg), the training protocol consisted of hydrogymnastics sessions 5 times per week during 12 weeks of intervention, executed in a pool of 1.3 meters divided into three phases: a 10 minute warm-up, 30 minutes of aerobic exercise at 50-60\% of maximum heart rate (monitored by heart rate monitor) and a 10 minute cool down. As a statistical method to compare the results between groups of variables pre and post training, the analysis of variance (ANOVA) mixed 2 X 2 (group X measurement) test was done using SPSS version 17. The findings showed no significant increase in measurements of muscle body composition component; no significant changes in fatty tissue of body composition were observed. These results were similar and congruent with studies carried out previously in elderly adults, where physical exercise programs, during which the subjects are active for less than 30 minutes, three times a week, lead to small or no changes in body mass and body composition.

KEY WORDS: Physical Activity; Elderly; Body Composition.

\section{INTRODUCTION}

Aging is defined as the natural sequence of processes that occur from birth until death and is characterized by the progressive decline of the body's physiological capabilities, as it also happens over all systems and organs (Fulop et al., 2010). In populations after the age of 60 appear the highest rates of health morbidity problems and the need for medical care, which affect the elderly's social development and decreases their quality of life (de Souza Santos et al., 2011). Older adults present a natural progressive loss of physical capacities and a dysfunction of the musculoskeletal system by gradual changes in their body mass index as well as body composition, decreasing muscle mass and bone mineral density and increasing the body fat mass content (Diaz et al., 2011; Rolland et al., 2009).

These effects result in an unbalance of motricity, becoming more weak (Guzmán et al., 2011; Ochoa-Martínez et al., 2012), predisposing the elderly to have lower functional autonomy in activities of daily living such as walking, climbing stairs, or rising from a chair without the help of a person or device (Molt \& McAuley, 2010; Behpoor et al., 2011).

The kinanthropometry has been defined as the quantitative interface of the anatomy and physiology or between human structure and function (Vangrunderbeek $e t$ al., 2013) the human body is composed of a variety of different tissue types including lean tissues muscle, bone, and organs that are metabolically active, and fat adipose tissue that is not (Norton \& Olds, 1996); In the field of medicine the assessment of body composition has been associated body fat mass content with a variety of risk factors for health and the presence of chronic degenerative pathologies (Mishra et al., 2013; Liu et al., 2014) the

* Faculty of Sports, Autonomous University of Baja California (UABC), Mexicali, Mexico.

** Postgraduate StrictoSensu Euro-American Network of Human Kinetics (REMH), Rio de Janeiro, Brazil.

**** Laboratory of Human Motricity Biosciences (LABIMH), Federal University of State of Rio de Janeiro, Brazil. 
evolution of changes in body composition in the sedentary elderly it is manifested differently with respect to elderly people who exercise consistently (Mishra et al.; Pillard et al., 2011).

Evidence from experimental exercise studies carried out in elderly adults, showed that multiple benefits are obtained in body composition increasing muscle mass and decreasing fat mass (Lee et al., 2013; Ruiz-Montero et al., 2013). It is important to plan and prescribe adequate exercise for the needs of elderly adults and to minimize their health problems, this in turn, will provide them an adequate level of physical performance, the latter which is crucial in order to maintain good overall health (American College of Sports Medicine et al., 2009). The present study proposes the answers to remaining questions: Can a hydrogymnastics exercise program get benefits in body composition (fat mass, muscle mass, bone mass and residual mass) in elderly women?

This study considered the hydrogymnastics as an exercise carried out through realizing rhythmic-gymnastic activities in an aquatic environment, the latter which simultaneously counteracts gravity and increases physical capabilities (Kamioka et al., 2010), this type of exercise is especially recommended for people who have limitations with exercise on dry land (Kamioka et al., 2011) and which in the last ten years, has taken popularity and preference among elderly adults by taking advantage of the properties of water in order to provide fluidity and a wider range in movements while diminishing the risk of injuries due to impact (Kamioka et al., 2010, 2011).

In the study, hydrogymnastics was identified as the independent variable and body composition (fat mass, muscle mass, bone mass and residual mass) as the dependent variable, with the objective being to evaluate the effect of a hydrogymnastics exercise program on body composition in elderly women. Two hypotheses were established (scientific and statistical); Our scientific hypothesis anticipates that after adult women joined hydrogymnastics program, noticeable improvement occurred in body composition components body fat and fat-free mass (muscle mass, bone mass and residual mass) in relation to sedentary women. We present the statistical hypothesis in null and alternative form, establishing as the acceptance or relative criteria, $\mathrm{p}<0.05$, level.

\section{MATERIAL AND METHOD}

The sample was composed of elderly adult women defined as women above the age of 60 years of age according to the World Health Organization (Gonzalez \& Ham-Chande,
2007), the elderly women were volunteer participants from the county of Mexicali in Baja California, Mexico.

According to the National Institute of Geography and Statistics (INEGI), the state of Baja California had an elderly adult to total population percentage of $6.9 \%$, corresponding to 229,914 people, of which $60 \%$ were women and $40 \%$ were men. In the city of Mexicali, Baja California the total population of elderly adults constitutes 64,640 which are considered the universe.

The inclusion criteria were: woman, 60 years of age or above, be a resident of the Mexicali county in Baja California, Mexico; be willing to volunteer as a participant in the study; not to have participated in any sort of systemized exercise program for at least three months prior to this study and to be physically able to join daily activities without the need of medical assistance.

The exclusion criteria for this study were: to possess any sort of acute or chronic complication that would hinder hydrogymnastics exercise, such as heart problems, diabetes mellitus, hypertension or asthma; physical complications that could affect the ability to accomplish exercise such as osteoarthritis, joint injuries or recent bone fractures, psychological and neurological problems, having had a major surgery in the past six months.

Observing the inclusion and exclusion parameters established for this intervention program, an n sample of 25 elderly women was calculated. At the beginning of this investigation 31 subjects were divided randomly through a simple raffle into a control and an experimental group but due to various health and personal reasons there were losses in both groups throughout the length of the investigation. At the end of the investigation 26 elderly women were counted, the losses coming mostly from the control group, an amount which was considered adequate for the size of the sample groups. The control group was composed of 10 elderly women who did not participate in a hydrogymnastics program; this group maintained their normal everyday activities without realizing any sort of systematic physical activity during 12 weeks while the experimental group, composed of 16 elderly women, performed hydrogymnastics exercise.

The present study followed the ethical principles regarding human experimentation proposed by the Helsinki declaration (Puri et al., 2009). The facility that was used to carry out this investigation, evaluating and applying the pilot program in the control and experimental group, was the Aquatic Complex of the School of Sports of the Autonomous University of Baja California in Mexico. 
All the participants signed a letter of consent in order to participate in the investigation, which explained the objective of the investigation, its evaluation protocols, possible risks, benefits, consequences, emergency procedures and consensus of participation as a volunteer. The investigation was submitted for evaluation by the ethics committee which is involved in studies on human beings, through the research program of the School of Sports of the Autonomous University of Baja California.

To determine the body composition the following measurements were taken: body weight $(\mathrm{cm})$, height $(\mathrm{cm})$, eight skinfolds (mm) triceps, sub scapular, biceps, iliac crest, supra spinal, abdominal, front thigh, medial calf, eleven circumferences (cm) arm relaxed, flexed arm, forearm, wrist, chest, low waist, high hip, thigh, buttock $1 \mathrm{~cm}$, mid-thigh, calf and ankle, and two bone diameters $(\mathrm{cm})$ humeral and femur. The equipment used was a Seca 220 scale and stadiometer, and the Rosscraft Inc. Tomkit (Slim guide skinfold caliper, bone diameter vernier and Lufkin metal anthropometric tape). Body composition analysis was calculated by Boris Anthropometric Software (Olds \& Norton, 1988); Anthropometric measurements were conducted by a level two antropometrist following the guidelines set by the International Society for Advancement of Kinanthropometry (ISAK) with a technical error of measurement less or equal to $1 \%$ (Marfell-Jones et al., 2006).

The subjects of this study were put through a hydrogymnastics program of moderate aerobic intensity in accordance with the standards established by the American College of Sports Medicine (American College of Sports Medicine et al.). The program consisted of 60 hydrogymnastics sessions with an exercise frequency of 5 times a week. The volume was set to 50 minutes per session, this being divided into 10 minutes of warm-up, 30 minutes of workload with progressively incremental intensities of $50 \%$ of maximum heart rate frequency for the first 6 weeks and $60 \%$ for the final 6 weeks of the program, using the formula Max HR= $208-0.7 x$ age (Tanaka et al., 2001), exercising through alternating movements between arms and legs, monitored using a heart rate monitor Polar FT7® (Finland) followed by 10 minutes of relaxation.

The statistical procedures proposed for an adequate analysis of this investigation were to characterize the sample and evaluate the hypothesis in the following manner: Using descriptive statistical techniques the investigated universal sample was characterized and a description of the evaluated data was produced. Utilizing methods of localization and dispersion in the standard deviation was then calculated and used to verify the sample symmetry, the acquired statistical results were processed into charts and graphs using SPSS
17 software. Shapiro-Wilkes test was used in order to determine the normality of the groups and the homogeneity of the sample (Thomas et al., 2001).

With the goal of establishing all the possibilities of comparison inter and intra group mixed 2 x 2 (groups $\mathrm{x}$ measurements) (ANOVA) variance analysis tests were performed for the variables of Body fat $(\mathrm{Kg})$ and Fat-free mass $(\mathrm{Kg})$ with the purpose of maintaining the scientific validity of the investigation. The significance level of $\mathrm{p}<0.05$, $95 \%$ probability of accuracy of the results or negative event with a probability of $5 \%$ per case. Percentage changes $(\Delta \%)$ were also calculated for each study group [(Media post Media pre)/Media pre] x 100 (Thomas et al.; Vincent, 1999).

\section{RESULTS}

The participating subjects in the present study were 26 elderly women divided randomly into one experimental group $n=16$, age of $67.5 \pm 5.4$ years old that partook in the hydrogymnastics exercise program and one control group $n=10$, age of $67.4 \pm 4.7$ years old that did not take part of the exercise program, the mean and standard deviation of anthropometric characteristics of the subjects can be observed in Table I.

For the variables of body composition, mixed $2 \times 2$ (group x measurements) (ANOVA) variance analysis tests were realized, establishing the level of significance a priori to $a \leq 0.05$. The results of the ANOVA $2 \times 2$ tests repeated showed no statistically significant measurements $(\mathrm{p}=0.622)$ between the groups and the measurements of the variable in the experimental group, there were no statistically significant changes found in the control group $(p=0.745)$ (Fig. 1). The results of the ANOVA $2 \times 2$ tests of Fat-free mass repeated showed no statistically significant measurements $(p=0.732)$ between the groups and the measurements of the variable in the experimental group, there were no statistically significant changes found in the control group ( $\mathrm{p}=0.542)$ (Fig. 2).

The percentage changes $(\Delta \%)$ of the variables of body composition for each study group were calculated [(Mediapost - Mediapre)/Mediapre] x 100. The evidence showed a percentage change in the experimental group $(\mathrm{n}=16)$ of Body fat $(\mathrm{Kg})$ was -5.57 in comparison with 12.70 from the control group $(n=10)$ (Fig. 3$)$. The results showed the percentage change of Fat-free mass $(\mathrm{Kg})$ in the experimental group $(n=16)$ of Fat-free mass $(\mathrm{Kg})$ was 3.80 in comparison with 0.96 from the control group $(n=10)$ (Fig. 4). 
Table I. Descriptive statistics $(\mathrm{M} \pm \mathrm{SD})$ of the volunteer women in the study $(\mathrm{n}=26)$.

\begin{tabular}{lcccc}
\hline \multirow{2}{*}{$\begin{array}{l}\text { Anthropometric } \\
\text { Variables }\end{array}$} & \multicolumn{2}{c}{ Experimental $(\mathbf{n}=\mathbf{1 6})$} & \multicolumn{2}{c}{ Control $(\mathbf{n}=\mathbf{1 0})$} \\
\cline { 2 - 5 } & Pre & Post & Pre & Post \\
\hline Weight $(\mathbf{K g})$ & $74.09 \pm 10.74$ & $73.27 \pm 10.81$ & $76.26 \pm 15.17$ & $76.29 \pm 15.70$ \\
Height $(\mathbf{c m})$ & $155.95 \pm 5.78$ & $155.90 \pm 5.72$ & $153.20 \pm 5.86$ & $152.41 \pm 6.19$ \\
BMI $(\mathbf{K g} / \mathbf{m} 2)$ & $30.53 \pm 0.9$ & $30.16 \pm 4.55$ & $32.60 \pm 6.91$ & $32.97 \pm 7.19$ \\
Body fat $\mathbf{( K g )}$ & $32.3 \pm 8$ & $30.5 \pm 7$ & $33.5 \pm 6$ & $32.9 \pm 5$ \\
Fat-free mass $(\mathbf{K g})$ & $34.2 \pm 5$ & $35.5 \pm 3$ & $35.2 \pm 1$ & $34.9 \pm 3$ \\
\hline
\end{tabular}

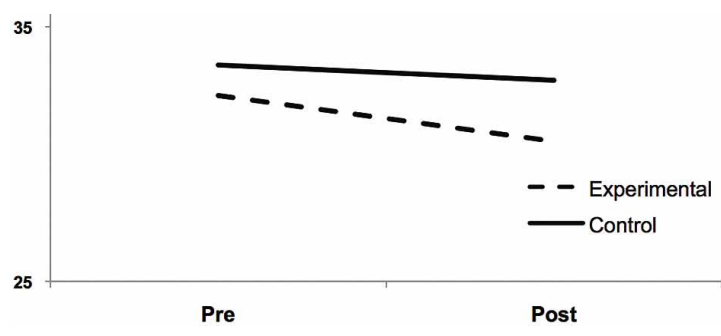

Fig. 1. Changes in the Body fat $(\mathrm{Kg})$ among the participants of the study $(n=26)$.

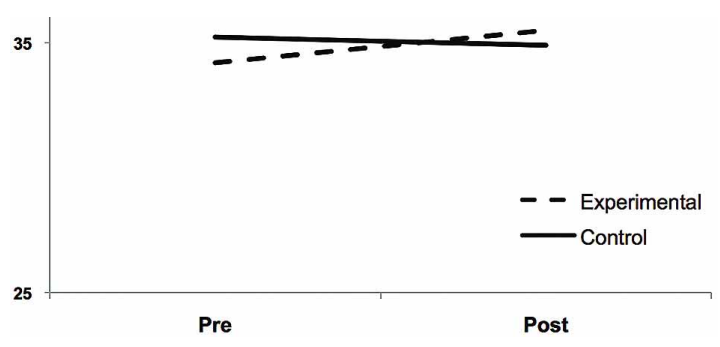

Fig. 2. Changes in the Fat-free mass $(\mathrm{Kg})$ among the participants of the study $(n=26)$.

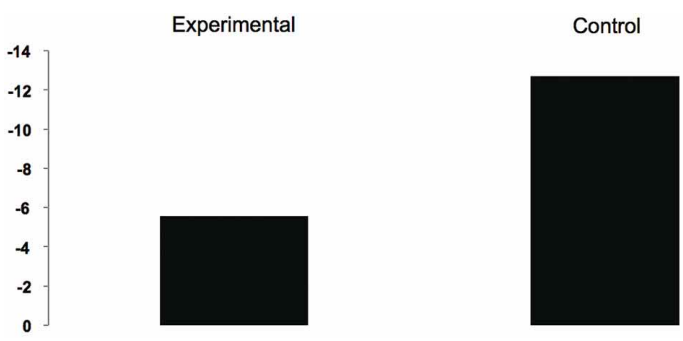

Fig. 3. Percentage changes $(\Delta \%)$ on the Body fat $(\mathrm{Kg})$ among the participants of the study $(n=26)$.

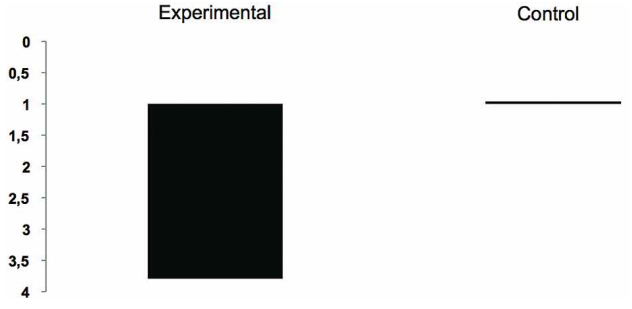

Fig. 4. Percentage changes $(\Delta \%)$ on the Fat-free mass $(\mathrm{Kg})$ among the participants of the study $(n=26)$.

\section{DISCUSSION}

In the present study aerobic training was emphasized and the recommendations for prescribing exercise for elderly adults set by the American College of Sports Medicine (American College of Sports Medicine et al.) and the American Heart Association (Nelson et al., 2007); these recommendations were followed by: Establishing the duration of the exercise program to 3 months and adapting the volume of training to 5 times per week with progressive overload beginning at $50 \%$ of maximum heart rate frequency for the first 6 weeks and $60 \%$ for the last 6 weeks; We observed that 12 -week hydrogymnastics training program did not increase significant measurements of muscle body composition component, neither significant changes in fatty tissue of body composition were observed. These results were similar and congruent with studies carried out previously in elderly adults, were physical exercise programs, during which the subjects are active for less than 30 minutes, three times a week, lead to small, or no changes in body mass and body composition (Valentine et al., 2009).

Results of studies referring to change in body composition during the realization of physical exercise which leads to lipolysis, are most probably caused by the increased consumption of energy, thus reducing body fat by using is as the primary energy source, which in turn would not be compensated by a further increase in the intake of calories (Lee et al.). Exercises increase the ability to use fat and carbohydrates with an increase in fat reduction, which primarily takes place during low and medium intensity exercise (Rolland et al.) as was the case in our study was not reflected in the results. A systematic program of controlled dieting and exercise would greatly enhance the results obtained when evaluating body composition (Mishra et al.). However, in the current study environmental covariables that could have effectively altered the results obtained, such as lifestyle, diet and overall physical activity were not monitored or controlled.

In academic literature today there are few studies that show the effects of exercise on body composition in elderly adults. Based on the established hypothesis, it is conclusive that 3 months of hydrogymnastics training are not effective in positive changes of Body fat and Fat-free mass, in elderly adult women (Hall- 
López et al., 2014). However, further studies must be performed in order to corroborate the results obtained on this variable from a hydrogymnastics program. Methodological designs of subsequent studies must present changes such as: a longer hydrogymnastics training program, evaluation of the effects of post-training rest on the variable, application in both sexes cand in different age groups, a larger " $n$ " sample that in return will provide more validity to the inferential statistic when analyzing the results of the experiment while consequently providing the possibility to extrapolate the results to subjects with similar characteristics. The express purpose of these studies would be to obtain results that could serve as a reference for planning, execution and evaluation of future interventions directed at preventing, minimizing and/or eliminating the predisposition of elderly adults to suffer from metabolic and cardiovascular diseases. This in turn, will help researchers and professionals who work with this segment of the population to better understand more factors in order to provide better attention.

\section{ACKNOWLEDGMENTS}

The research was funded by internal call number 16 th of research project from the Autonomous University of Baja California UABC; Grant 149/2/C/13/16.

OCHOA, M. P. Y.; HALL, L. J. A.; ALARCÓN, M. E. I.; PIÑA, D. D. \& ESTÉLIO, H. M. D. Efecto de tres meses de un programa de ejercicio acuático en la composición corporal de adultas mayores. Int. J. Morphol., 32(4):1248-1253, 2014.

RESUMEN: El objetivo de la presente investigación fue evaluar el efecto de un programa de hidrogimnasia sobre la masa grasa y masa libre de grasa en 26 mujeres adultas mayores divididas en grupo experimental $(n=16)$ y un grupo control $(n=10)$. Las variables antropométricas fueron valoradas utilizando los lineamientos establecidos por ISAK para determinar la masa grasa y masa libre de grasa. Las sesiones de hidrogimnasia fueron 5 veces por semana por un periodo de 12 semanas, con ejercicios aerobicos del 50-60\% de la FCmáx monitoreada por pulsómetro polar-FT7. Para los cálculos se utilizó la prueba de ANOVA, no encontrando diferencias significativas en la masa grasa y masa libre de grasa del grupo experimental en relación al grupo control. Estos resultados fueron similares y congruentes a estudios realizados en adultos mayores, con actividad física, donde los sujetos participaron al menos 30 minutos tres veces a la semana, no encontrando cambios en la composición corporal.

PALABRAS CLAVE: Actividad física; Adultos mayores; Composición corporal.

\section{REFERENCES}

American College of Sports Medicine; Chodzko-Zajko, W. J.; Proctor, D. N.; Fiatarone Singh, M. A.; Minson, C. T.; Nigg, C. R. Salem, G. J. \& Skinner, J. S. American College of Sports Medicine position stand. Exercise and physical activity for older adults. Med. Sci. Sports Exerc., 41(7):1510-30, 2009.

Behpoor, N.; Darabi, M. R.; Hojatoleslami, L.; Bayat, P. D. \& Ghanbari, A. The effect of a group exercise program on muscular function among fall-prone elderly women. Int. J. Morphol., 30(2):567-71, 2012.

de Souza Santos, C. A.; Dantas, E. E. \& Moreira, M. H. Correlation of physical aptitude; functional capacity, corporal balance and quality of life (QoL) among elderly women submitted to a post-menopausal physical activities program. Arch. Gerontol. Geriatr., 53(3):344-9, 2011.

Diaz, J.; Espinoza-Navarro, O.; Rodríguez, H. \& Moreno, A. Prevalence of anthropometric and physiological patterns in the elderly population over 60 years in Arica, Chile. Int. J. Morphol., 29(4):1449-54, 2011.
Fulop, T.; Larbi, A.; Witkowski, J. M.; McElhaney, J.; Loeb, M.; Mitnitski, A. \& Pawelec, G. Aging, frailty and age-related diseases. Biogerontology, 11(5):547-63, 2010.

Gonzalez, C. A. \& Ham-Chande, R. Functionality and health: a typology of aging in Mexico. Salud Pública Mex., 49(Suppl. 4):448-58, 2007.

Guzmán, R. A.; Salazar H. A.; Cea, A.; Melián, H. P.; Cordier, B. \& Silvestre, R. A. Correlation between the Scores of "Timed up and go" Test and Registered Joint Moments of Lower Limb During the Sit-to-Stand Transfer in Elderly with Antecedents of Frequent Falls. Int. J. Morphol., 29(2):5215,2011

Hall-López, J. A.; Ochoa-Martínez, P. Y.; Alarcón-Meza, E. I.; Anaya-Jaramillo, F. I.; Botelho-Teixeira, A. M. M.; MoncadaJiménez, J.; Ferreira-Reis, J. C. \& Martin Dantas, E. H. Effect of a hydrogymnastics program on the serum levels of highsensitivity C-reactive protein amongst elderly women. Health, 6(1):80-5, 2014. 
Kamioka, H.; Tsutani, K.; Okuizumi, H.; Mutoh, Y.; Ohta, M.; Handa, S.; Okada, S.; Kitayuguchi, J.; Kamada, M.; Shiozawa, N. \& Honda, T. Effectiveness of aquatic exercise and balneotherapy: a summary of systematic reviews based on randomized controlled trials of water immersion therapies. $J$. Epidemiol., 20(1):2-12, 2010.

Kamioka, H.; Tsutani, K.; Mutoh, Y.; Okuizum, H.; Ohta, M.; Handa, S.; Okada, S.; Kitayuguchi, J.; Kamada, M.; Shiozawa, N.; Park, S. J.; Honda, T. \& Moriyama, S. A systematic review of nonrandomized controlled trials on the curative effects of aquatic exercise. Int. J. Gen. Med., 4:239-60, 2011.

Lee, B. A.; Kim, J. G. \& Oh, D. J. The effects of combined exercise intervention on body composition and physical fitness in elderly females at a nursing home. J. Exerc. Rehabil., 9(2):298303,2013

Liu, L. K.; Lee, W. J.; Chen, L. Y.; Hwang, A. C.; Lin, M. H.; Peng, L. N. \& Chen, L. K. Sarcopenia, and its association with cardiometabolic and functional characteristics in Taiwan: results from I-Lan Longitudinal Aging Study. Geriatr. Gerontol. Int., 14(Suppl. 1):36-45, 2014.

Marfell-Jones, M.; Olds, T.; Stewart, A. \& Carter, L. International standards for anthropometric assessment. Potchefstroom, ISAK, 2006.

Mishra, S.; Harris, T. B.; Hue, T.; Miljkovic, I.; Satterfield, S.; de Rekeneire, N.; Mehta, M. \& Sahyoun, N. R. Hyperleptinemia, adiposity, and risk of metabolic syndrome in older adults. $J$. Nutr. Metab., 2013:327079, 2013.

Motl, R. W. \& McAuley, E. Physical activity, disability, and quality of life in older adults. Phys. Med. Rehabil. Clin. N. Am., 21(2):299-308, 2010.

Nelson, M. E.; Rejeski, W. J.; Blair, S. N.; Duncan, P. W.; Judge, J. O.; King, A. C.; Macera, C. A.; Castaneda-Sceppa, C.; American College of Sports Medicine \& American Heart Association. Physical activity and public health in older adults: recommendation from the American College of Sports Medicine and the American Heart Association. Circulation, 116(9):1094-105, 2007.

Norton, K. \& Olds, T. Antropométrica. Marrickville, Sidney, Southwood Press, 1996.

Ochoa-Martínez, P. Y.; Hall-López, J. A.; Alarcón-Meza, E.; Rentería, I.; Botelho Teixeira, A. M. M.; Lara-Zazueta, H. \& Martin Dantas, E. H. Comparison of Agility and Dynamic Balance in Elderly Women with Endomorphic Mesomorph Somatotype with Presence or Absence of Metabolic Syndrome. Int. J. Morphol., 30(2):637-42, 2012.

Olds, T. \& Norton, K. LifeSize. Educational software for body composition analysis. Adelaide, University of South Australia - Human Kinetics Software, 1988.
Pillard, F.; Laoudj-Chenivesse, D.; Carnac, G.; Mercier, J.; Rami, J.; Rivière, D. \& Rolland, Y. Physical activity and sarcopenia. Clin. Geriatr. Med., 27(3):449-70, 2011.

Puri, K. S.; Suresh, K. R.; Gogtay, N. J. \& Thatte, U. M. Declaration of Helsinki, 2008: implications for stakeholders in research. J. Postgrad. Med., 55(2):131-4, 2009.

Rolland, Y.; Lauwers-Cances,V.; Cristini,; C.; Abellan van Kan, G.; Janssen, I.; Morley, J. E. \& Vellas, B. Difficulties with physical function associated with obesity, sarcopenia, and sarcopenic-obesity in community-dwelling elderly women: the EPIDOS (EPIDemiologie de l'OSteoporose) Study. Am. J. Clin. Nutr., 89(6):1895-900, 2009.

Ruiz-Montero, P. J.; Castillo-Rodríguez, A.; Mikalacki, M.; Nebojsa, C. \& Korovljev, D. Previous Anthropometric Measures in Adult and Elderly Serbian Women to Physical and Educational Program Of Pilates And Aerobic. Int. J. Morphol., 31(4):1263-8, 2013.

Tanaka, H.; Monahan, K. D. \& Seals, D. R. Age-predicted maximal heart rate revisited. J. Am. Coll. Cardiol., 37(1):153-6, 2001.

Thomas, J. R.; Nelson, J. A. \& Silverman, S. J. Research Methods in Physical Activity. 6th ed. Champaign, Illinois, Human Kinetics, 2001.

Vangrunderbeek, H.; Claessens, A. L. \& Delheye, P. Internal social processes of discipline formation: the case of kinanthropometry. Eur. J. Sport Sci., 13(3):312-20, 2013.

Valentine, R. J.; Misic, M. M.; Rosengren, K. S.; Woods, J. A. \& Evans, E. M. Sex impacts the relation between body composition and physical function in older adults. Menopause, 16(3):518-23, 2009.

Vincent, W. J. Statistics in kinesiology. 3rd ed. Champaign, Ilinois, Human Kinetics, 1999.

\author{
Correspondence to: \\ Javier Arturo Hall López \\ Faculty of Sports \\ Autonomous University of Baja California (UABC) \\ Mexicali \\ MEXICO
}

Email: javier@uabc.edu.mx

Recibido: 23-04-2014

Aceptado: 18-08-2014 